\title{
Sustainability in complex projects of civil construction: bibliometric and bibliographic review
}

\section{Sustentabilidade em projetos complexos da construção civil: uma análise bibliométrica e bibliográfica}

\author{
Josivan Leite Alves ${ }^{1}$ (), Igor Bernardino Borges ${ }^{2}$ (1), Jeniffer de $\mathrm{Nadae}^{3}$ () \\ 1Universidade de São Paulo - USP, São Paulo, SP, Brasil. E-mail: josivanleite3@gmail.com \\ 'Universidade Federal de Pernambuco - UFPE, Recife, PE, Brasil. \\ ${ }^{3}$ Universidade Federal de Itajubá - UNIFEI, Itajubá, MG, Brasil
}

How to cite: Alves, J. L., Borges, I. B., \& Nadae, J. (2021). Sustainability in complex projects of civil construction: bibliometric and bibliographic review. Gestão \& Produção, 28(4), e5389.

https://doi.org/10.1590/1806-9649-2020v28e5389

\begin{abstract}
The complexity that surrounds the construction projects ends up hampering the balance between economic, environmental and social issues. In this context, this research aims to know the behavior of international scientific production relating sustainability to complex projects, through a systematic literature review and bibliometric indicators. It was searched for articles that related the terms "project *", "complex *", "sustainability", "building OR civil construction" in the Scopus database, resulting in a sample of 331 articles. There is a tendency of studies on the subject from 2006, where the articles, for the most part, seek to understand the consequences and complexity in the implementation of works, through case studies. The sample obtained also showed that the American researchers lead in quantity of research and are the most cited. Finally, the emerging international interest in sustainable construction may correlate with the growing number of green buildings and the existing certifications that characterize sustainable buildings.
\end{abstract}

Keywords: Sustainability civil construction; Complex projects; Bibliometric.

Resumo: A complexidade que envolve os projetos da construção civil acaba dificultando o equilíbrio entre as questões econômicas, ambientais e sociais. Nesse contexto, esta pesquisa objetiva conhecer o comportamento da produção científica internacional relacionando a sustentabilidade em projetos complexos, por meio de uma revisão sistemática da literatura e de indicadores bibliométricos. Buscouse na base de dados Scopus artigos que relacionassem os termos "project *", "complex", "sustainability", "building OR civil construction", resultando em uma amostra de 331 artigos. Há uma tendência de estudos sobre o tema a partir de 2006, onde os artigos, em sua maioria, buscam compreender as consequências e a complexidade na execução dos trabalhos, por meio de estudos de caso. A amostra obtida também mostrou que os pesquisadores americanos lideram em quantidade as pesquisas e são os mais citados. Por fim, o interesse internacional emergente na construção sustentável pode se correlacionar com o número crescente de edifícios verdes e as certificações existentes que caracterizam edifícios sustentáveis.

Palavras-chave: Sustentabilidade; Construção civil; Projetos complexos; Bibliometria.

Received Dec. 16, 2019 - Accepted Mar. 8, 2021

Financial support: This study was financed in part by the Coordenação de Aperfeiçoamento de Pessoal de Nivel Superior - Brasil (CAPES).

This is an Open Access article distributed under the terms of the Creative Commons Attribution License, which permits unrestricted use, distribution, and reproduction in any medium, provided the original work is properly cited. 


\section{Introdução}

By the middle of 2017 the world population was approximately 7.6 billion, a growth of about one billion inhabitants in the last twelve years (that number can reach 8.6 billion by 2030) (United Nations, 2017). Such growth requires infrastructure (mainly in developing countries), produces large urban and infrastructure projects such as water and sewage, electricity, transportation and telecommunications (Hu et al., 2015). However, the implementation of urban infrastructure entails negative environmental, social and economic consequences generated by the expressive amount of solid waste in the construction industry and its incorrect destination impose the need for effective reuse alternatives and final disposal solutions. Such alternatives should be predicted in the projects, since it is the same in the beginning of the life cycle of a construction (Csillag, 2007).

However, uncertainties and instability of projects are due to factors such as sustainability, technology, changes in power relations in geopolitics, and retention of qualified individuals who can adapt to changes in the operating environment (Gorod et al., 2018). In the context of sustainability, projects assume key roles for the development and implementation of sustainable technologies and practices (Silvius \& Schipper, 2014). The designer, in this case, must recognize the impacts of each choice, seeking sustainability requirements applicable throughout the different phases of the life cycle of the building, from its conception, during its useful life, to management of building waste in phase (Akadiri et al., 2012), for example.

In this perspective, sustainable preventive projects and measures are necessary and essential, since human and ecological effects must be approached as factors in open, dynamic and multiscale systems with a considerable degree of complexity and uncertainty (Gibson, 2006). Sustainable projects assess the purposes, options, impacts, mitigation and possibilities of improvement of their activities, as well as monitor and control the lessons learned during their development (Gibson, 2006).

It is worth mentioning that urban infrastructure projects, for the most part, are characterized as a megaproject (an example of a complex project). Most construction projects are considered complex because they involve a management that combines the various projects and contractual arrangements, using the most varied team skills for the construction itself and even the facilities (van Marrewijk et al., 2008). In addition, they are characterized by a significant extension and difficulty in understanding planning processes due to their high initial uncertainty of data, high probability of risk, multi-level task structure and variety of interconnections, high number of specialized professionals and approaches involved in the project (Kritskiy et al., 2018).

Thus, the implementation and management of sustainability in complex projects ends up being an arduous task. The alignment between the product portfolio and environmental sustainability introduces that the decisions to be taken from the environmental point of view in portfolio management take into consideration: Strategic alignment: the projects must be integrated with the sustainability agenda of the organization; Brand: the projects should reinforce the positioning of the company in relation to sustainability; Emission of $\mathrm{CO} 2 /$ biomaterials: the projects must contribute to reach zero emission levels and be based on biomaterials; Leveraging technological capabilities: enhancing the 
organization's technological capabilities in relation to sustainability (Brook \& Pagnanelli, 2014).

Thus, this article aims to analyze the publications that correlate complex projects and sustainability, through a bibliometric and systematic literature review, in which we searched for articles with the terms: "project *", "complex *", "Sustainability", "building OR civil construction" in the Scopus database.

This paper is divided in 5 sections: the first one presents the Introduction of the themes treated in the research; theoretical reference, titled sustainability in complex civil construction projects, in which concepts about the theme are exposed; in the third section, we present the methodology used by the authors to reach the objectives; the Analysis of Results are presented in section 4, followed by the Conclusions.

\section{Sustainability in complex construction projects}

Sustainability is characterized as a participatory process that conceives and develops a community sense in which it proposes the respect and prudent use of natural resources, seeking, as far as possible, economic security, promoting democracy and popular participation in the control of their communities, maintaining the integrity of ecological and vital systems (Gladwin et al., 1995). It is the simultaneous maximization of the objectives of: biological system by genetic diversity, resilience, biological productivity); economic system by meeting the basic needs, equality and growth of useful goods and services; and, finally, social system by promoting cultural diversity, institutional sustainability, social justice, participation (Barbier, 1987).

This concept is based on the Triple Bottom Line-TBL, since it takes into account the social, environmental and economic aspects (Elkington, 1994). There is a need for sustainable measures that integrate the foundations of TBL into the processes of the construction industry.

It is worth noting that the Brundtland report, better known as Our Common Future, defined sustainable development as being "[...] one that meets the needs of the present without compromising the ability of future generations to meet theirs [...]" (Brundtland, 1987, p. 57). Sustainability in enterprises needs to incorporate sustainable development objectives, which are social equity, economic efficiency and environmental performance in an organization's operational practices and projects (Martens \& Carvalho, 2017). This change in production and consumption patterns, within the scope of sustainable development, requires innovative projects and changes related to business strategies, which directly changes the management of projects (Silvius et al., 2016). In this way, sustainable projects will become viable as energy costs return, pressures from consumer groups increase due to greater transparency in supply chains and companies begin to have a more holistic view of the costs and benefits associated with social and environmental projects (Carter \& Rogers, 2008).

Dyllick \& Hockerts (2002, p. 132) analyze the capital application of a company according to the three dimensions of the TBL, as shown in Table 1. 
Table 1. Application of the company's capital in TBL dimensions.

\begin{tabular}{cl}
\hline Dimension & \multicolumn{1}{c}{ Application } \\
\hline Economic & $\begin{array}{l}\text { Ensure enough cash flow to ensure liquidity and } \\
\text { at the same time produce a persistent above- } \\
\text { average return from its stakeholders. }\end{array}$ \\
\hline Environmental & $\begin{array}{l}\text { Use of renewable natural resources, where } \\
\text { emissions do not exceed the capacity of the } \\
\text { natural system to absorb and assimilate } \\
\text { pollutants. }\end{array}$ \\
\hline Social & $\begin{array}{l}\text { Add value to the communities in which they } \\
\text { operate, raising the human capital of individual } \\
\text { partners, as well as promoting social capital so } \\
\text { that investors can understand their motivations } \\
\text { and agree with the company's value system. }\end{array}$ \\
\hline
\end{tabular}

Source: Adapted from Dyllick \& Hockerts (2002, p.132).

Thus, when developing a sustainable project, it is essential to identify the design elements of the built environment and their levels of importance from the point of view of sustainability (Yildiz et al., 2019). In addition, it is concerned with the products or services generated by it and their respective life cycle, not only being limited to the initiation, development, execution, testing and launch phases (Brent \& Labuschagne, 2006).

Sustainable projects seek green technologies and their strategies increase the quality of the building's internal environment, making it more conducive to human health and productivity (Romm \& Browning, 1998), and the project is a temporary effort, with a good start and end defined and not necessarily short-term employee to create a product or service (PMI, 2011). In addition, it has a clear and well-defined objective that consumes resources, working under labor pressure (Kerzner, 2012). The factors related to project size, project variety, project interdependence and project context can help to scale the complexity of a project (Vidal \& Marle, 2008).

According to the PMI (2018) to achieve the project aims there must be good management, which must have the application and qualified integration of processes involved. For Vargas (2005) the management of a project can be understood as a structured and logical process to deal with changes. Tools and techniques such as: management tools, quality control, costs and risks are important in conducting a project (PMI, 2018). These mechanisms developing skills, initiatives and strategies to achieve the best project results (Kameiya et al., 2016).

The difference between routine projects and complex projects is the degree of disorder, its instability, emergence, nonlinearity, recursion, uncertainty, irregularity and randomness, including high uncertainty about objectives (CCPM, 2008). In addition, it adds high monetary value and has a high public interest (FHWA, 2006). Kerzner (2013) argues that project complexity is one of the challenges that must be overcome for successful project management

A complex project has as main characteristic the involvement of more than one organization, consequently, several stakeholders and organizational systems, thus requiring an effective management of risks and uncertainties (PMI, 2011). In addition, it requires the mastery of techniques and tools that subsidize the project manager to success (Jiang et al., 2004).

Baccarini (1996, p. 201) observed that the literature defines two basic dimensions of complexity for projects, one consisting of "several interrelated stakeholders" and the other in "complicated, involved, intricate". The author notes that the first dimension is 
clearly delimited so that the complexity of the project can be operationalized in terms of: differentiation (the amount of varied elements such as tasks, specialists and components) and interdependence or connectivity (the degree of interrelation between elements). The second dimension, as suggested by the author, suggests a broad and diverse definition of interpretation, which may involve the project's difficulty in terms of project criticality, visibility and accountability, and clarity of scope definition, making such a definition subjective and observer dependent.

In general, the complexity of a project is related to its heterogeneity in terms of interdependencies, duration and scope of organization and relationship (Moore et al., 2018). In this perspective, the greater the complexity of the project, the greater the difficulties for the application of sustainable measures, in terms of aggression to the environment, the community involved and the budget limits.

The management of sustainability in projects is complex because its objectives must be clearly defined in each phase (Marcelino-Sádaba et al., 2015; Sánchez, 2015). However, project management makes it possible to implement sustainability in organizations at all stages and levels of business (Marcelino-Sádaba et al., 2015), since sustainability criteria can be incorporated into strategic planning (Maletič et al., 2014) and innovation (Morioka \& Carvalho, 2016). According to Martens \& Carvalho (2017) the integration of sustainability in project management influenced the project managers to direct efforts to reduce the consumption of resources in the project, mainly water and energy, with a focus on eco-efficiency and environmental impact .

In this sense, mapping sustainable development in project management processes and knowledge areas exposes the various opportunities for the insertion of sustainability guidelines in the most varied project management processes (Eid, 2009). In addition, the responsibility for sustainability may be different from one project to another, but the project manager always plays a decisive and/or influential role, being responsible for the effective implementation of sustainability (Silvius \& Schipper, 2014). When implemented in projects, sustainability assessment processes need to: Encourage project managers to consider potentially sustainable initiatives; consider interdependencies and seek multiple reinforcement gains across all fronts; specify the sustainability decision criteria and the trade-off rules for specific contexts (Gibson, 2006).

In order to implement sustainability in the construction environment, it is necessary to identify the demand for knowledge about environmental management in the project and to apply it, for example: in the planning of the scope, one must take into account the consequences that the project will bring to the environment in its surroundings and what changes in scope may be a viable option when a negative environmental impact is identified; and the inclusion of environmental management as an area of knowledge in the Project Analytical Framework (EAP).

Works and buildings projects, for example, take economic, social and environmental aspects into account in order to balance them. Figure 1 outlines the implementation structure of sustainability through three objectives to be followed (resource conservation, cost efficiency and human adaptation design) and their respective strategies. 


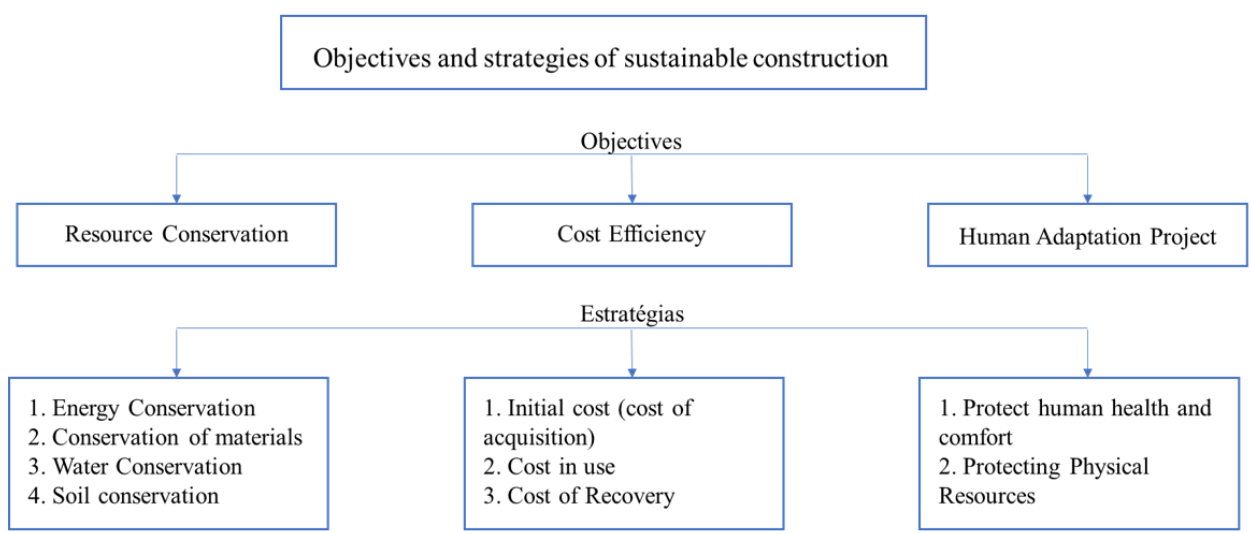

Figure 1. Implementation structure of sustainability in construction. Source: Adapted from Akadiri et al. (2012, p. 131)

These objectives are largely met by green buildings or "Green Buildings". They use resources such as energy, water, materials and soil more efficiently, invest in natural light and better air quality, thus raising the quality of life of their inhabitants (Kats, 2003). As natural resources are limited and their use must be treated with caution, one must choose to use renewable materials (Halliday, 2008).

To this end, some initiatives must be taken, such as: The development of energyefficient technological processes; Use of non-toxic and durable materials; Rainwater collection systems; Landscaping projects with low water demand; Implementation of water reuse projects; Adaptation of existing constructions; Insertion of construction project close to existing infrastructure, among others (Akadiri et al., 2012).

Finally, resource efficiency, human adaptation design, and cost efficiency form a framework for integrating sustainability principles into construction projects from the conceptual stage, in order to reduce these damaging impacts of construction on the environment and achieve sustainability in industry (Akadiri et al., 2012).

\section{Methodology}

The methodological approach used was a systematic review of the literature associated with bibliometrics, in which the objective is to analyze the literature on a particular theme, which in this case is to know the behavior of international scientific production related to sustainability in complex projects in civil construction. To this end, the Scopus database was consulted, whose basis provides a comprehensive overview of scientific production thanks to the number of indexed works.

Bibliometric presents itself as a relevant procedure for the visualization of scientific publication indicators. It is defined by Café \& Bräscher (2008, p. 54) as a set of laws and principles applied to statistical and mathematical methods aimed at mapping the scientific productivity of periodicals, authors and information representation. In addition, the bibliometric study was the alternative used in this research because its scientific approach allows evaluating the production of articles on a specific theme, identifying the academic communities and knowing the networks of researchers and their motivations (Chueke \& Amatucci, 2015). Among the advantages of this type of study are the system of review, originality of the results of the research, availability of literature and the more transparent limitation criteria (or rules of analysis) (Glänzel, 
2003). Two laws of bibliometric were used for the analysis of results, Bradford's law and Lotka's law.

Bradford's law "[...] allows, through the measurement of journal productivity, establishing the nucleus and areas of dispersion on a given subject in the same set of journals" (Vanti, 2002, p. 153). Lotka's law is based on the law of the inverse square, which states that the number of authors who make " $n$ " contributions in a given scientific field is " $1 / \mathrm{n} 2$ " of those who make only one contribution, only one contribution amounts to more or less $60 \%$ (Urbizagastegui, 2008).

Initially, a systematic search was made to obtain the research sample. For this, the Scopus database was used because it has 5,000 authors who publish on the platform, more than 71 million indexed documents and 23,700 periodicals, besides the fact that in this indexing platform it is possible to search by document, author or affiliation; use advanced search, refining results by source type, year, language, author, affiliation and others; and has a link to full-text articles that your institution already signs, along with other library resources (Elsevier, 2018). Only the Scopus database was used as a way of knowing the behavior of the research about the subject of this article contained in it. The second stage included the systematic analysis of the literature and bibliometric.

The systematic search was carried out in May 2018, limited to articles, with the terms "project *", "complex *", "sustainability", "building OR civil construction", where the database selected the titles, abstracts and keywords with the aforementioned terms, which resulted in 461 articles. Once again, the search was refined to the Portuguese and English languages, which made the sample decrease to 331 articles.

The 311 works forms the first sample of this research, from which bibliometric indicators were produced, such as: distribution of publications by year, country, research areas, main authors of themes and journals. For the content analysis, a filtering note was required. All the 311 abstracts were read with objective the filter those with specifically deal with sustainability in project complex. Thus, 131 articles remained. The articles in this new sample were read in their entirety, where most of the projects that they research, classified as complex, were construction projects. With this perception, it was possible to classify according of the proposed flowchart Akadiri et al. (2012, p. 131), under which it is exposed in Figure 2.

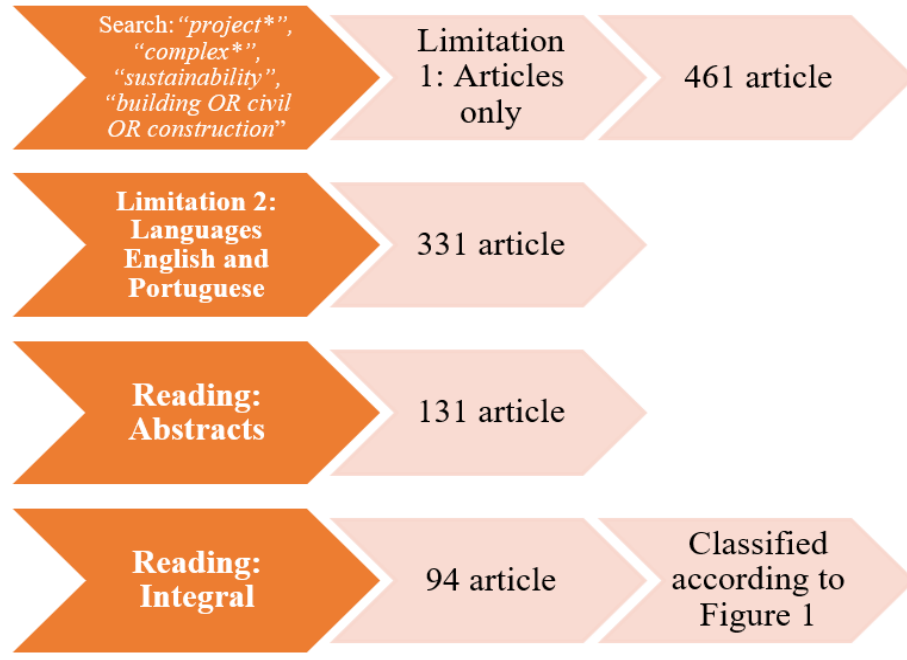

Figure 2. Methodology of the research. Source: Authors (2019). 
The analysis of the collected sample was carried out using two software Excel and VosViewer. VosViewer is a software for creation and visualization of bibliometric networks. It has the text mining function that can be used to construct and visualize co-occurrence networks of important terms taken from a database. It was used for the creation of networks of keywords and co-citation. Excel was used to create graphs, tables and tables that would provide the information needed for descriptive evaluations related to quantity and distribution of output, major authors, publications by area of expertise, and major journals. Thus, we analyzed the scientific productions and authors most cited in the database. With this, it was possible to know these works in full and to describe the methodologies, the study objectives and the respective institutions in which the authors are affiliated.

\section{Results}

This session is divided into two. The first presents the bibliometric indicators found by the research, analyzing them with the help of graphs and tables. The second session presents the percentage and classification of articles, as explained in the methodology.

\subsection{Bibliometric indicators}

Figure 3 shows the distribution of articles production during the years 1987 to 2018 , totaling 331 documents in the period during which the search was made. The horizontal line represents the average number of publications per year (about 10 jobs). During 17 years, the number of annual publications varies from 0 to 4 , having a growth from 2005 with 6 publications. And in the year 2017 was obtained a greater number of publications totaling 45 articles.

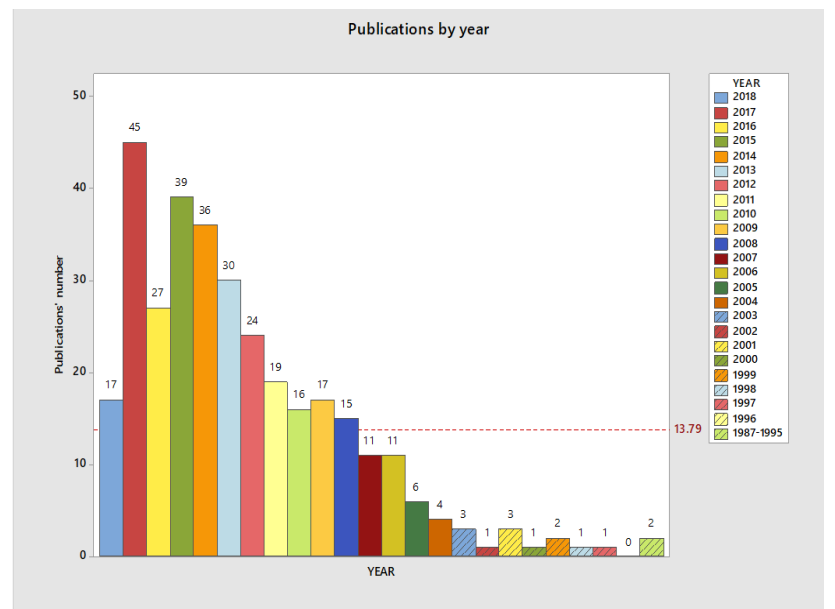

Figure 3. Publications by year. Source: Authors.

The first, and only, publication appeared in 1987 entitled: "Sustainable development of fragile lands: The case of extensive livestock production in Africa" by Gow, DD published in the journal Agricultural Administration and Extension, in which it has 3 quotes in Scopus. The author analyzes the problems associated with long-term sustainable development of fragile land in Africa and whether donor international assistance to the extensive livestock sector in Africa's semi-arid tropics has failed because of the associated project. 
In 2013, the number of productions reached 30 , showing the interest that the researchers had in the subject. For the knowledge of the approaches of these works, Table 2 exposes the most frequent theme that the productions approach from 2013 to 2018.

Table 2. Approaches with higher frequencies per year.

\begin{tabular}{lc}
\hline Year & Papers \\
\hline $\begin{array}{l}\text { Design of green buildings and technologies related to the sustainability of } \\
2013 \text { buildings, such as the use of green roofs and solar energy in homes, for } \\
\text { example. }\end{array}$ & 30 \\
\hline They analyzed the need to include knowledge related to construction \\
management and sustainability in higher education of engineers and the \\
2014 importance of architecture in the composition of a green project. In addition to \\
addressing case studies in which there have been modifications in buildings \\
to make them more sustainable. \\
$\begin{array}{l}\text { It was highlighted the importance that BIM (Building Information Modeling) * } \\
\text { has in civil construction to minimize waste and increase project sustainability, } \\
\text { while others have focused on the challenges in planning more sustainable } \\
\text { hospitals. }\end{array}$ \\
\hline $\begin{array}{l}\text { They address energy efficiency in buildings as an essential part of } \\
\text { sustainability in construction and reiterate the importance of architecture for } \\
\text { green building. In addition to emphasizing the importance of choosing more } \\
\text { sustainable materials for the realization of more sustainable constructions. }\end{array}$ & 27 \\
\hline $\begin{array}{l}\text { They reinforce the importance of BIM for the development of sustainable } \\
\text { projects and emphasize the importance of the triple bottom line in sustainable } \\
\text { construction. In addition to reporting the challenges for implementing a green } \\
\text { building. }\end{array}$ & 45 \\
\hline $\begin{array}{l}\text { Emphasis on the need to integrate sustainability into construction and a more } \\
\text { sustainable design in the early stages of a project. }\end{array}$ & 17 \\
\hline
\end{tabular}

Source: Authors (2019)

* Building Information Modeling (BIM) or Construction Information Modeling is a 3D visual representation methodology that is closer to reality because it considers the various variants of civil construction, making project execution more consistent with planning.

The survey data showed that the United States was the country that most produced articles on the subject (24\% of the works), followed by the United Kingdom ( $17 \%$ jobs) and Australia (25\% jobs), according to Figure 4 . It presents in the Figure 4 only countries with more than 5 publications on the selected topic.

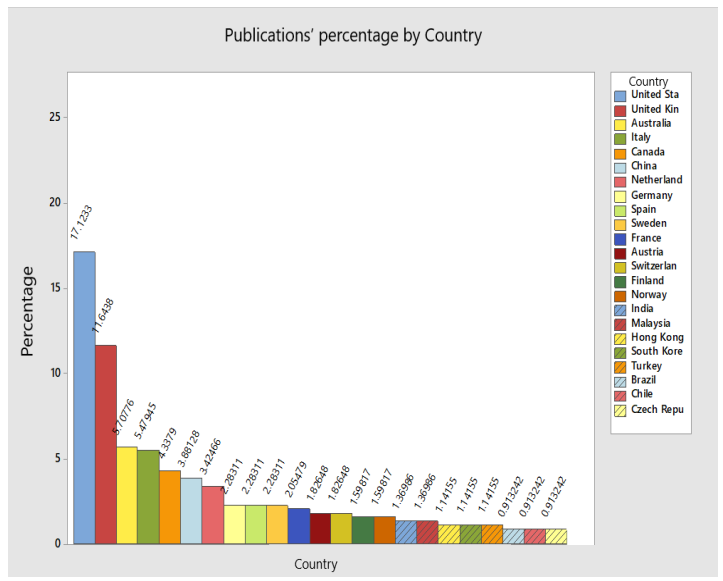

Figure 4. Countries that produced most articles on the topic. Source: Authors. 
The articles of the United States seek to analyze the impacts of containment works, bridges, dams, buildings or any urban infrastructure project. Another research from the same country addresses the complexity of implementing sustainability in different work environments and seeks educational alternatives as a solution tool.

Figure 5 shows the areas that published on the theme, with more than 100 works in the areas of Social Sciences (23\%), Engineering (20\%) and Environmental Science $(19 \%)$.

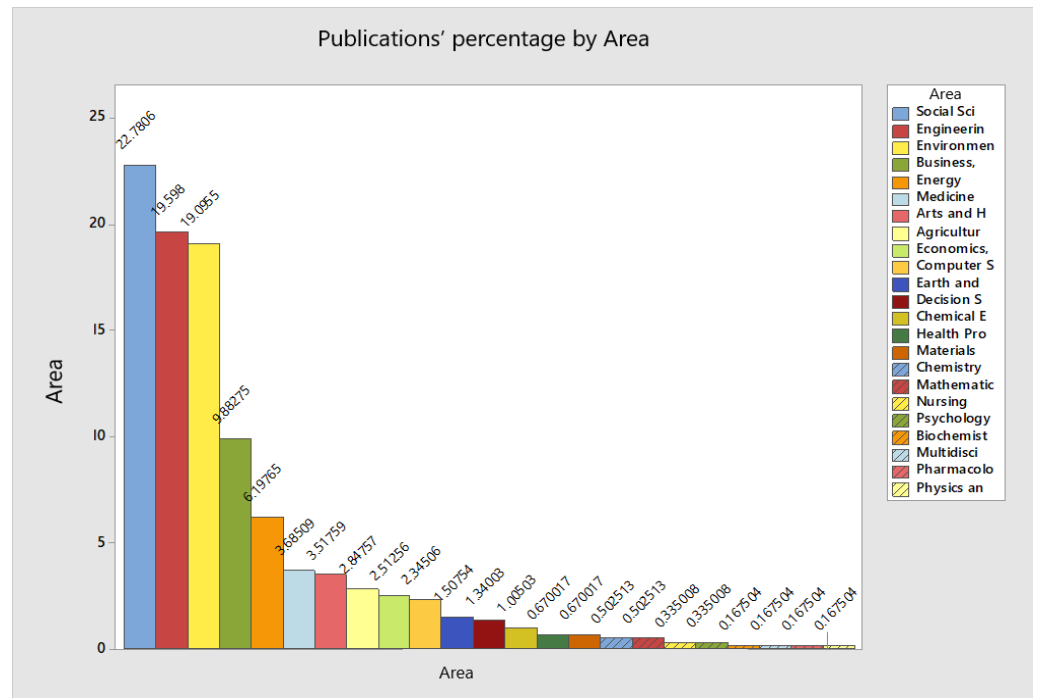

Figure 5. Research Areas. Source: Authors.

The research database provided 158 authors, of which 138 have only one publication and 17 have two publications, according to Figure 6.

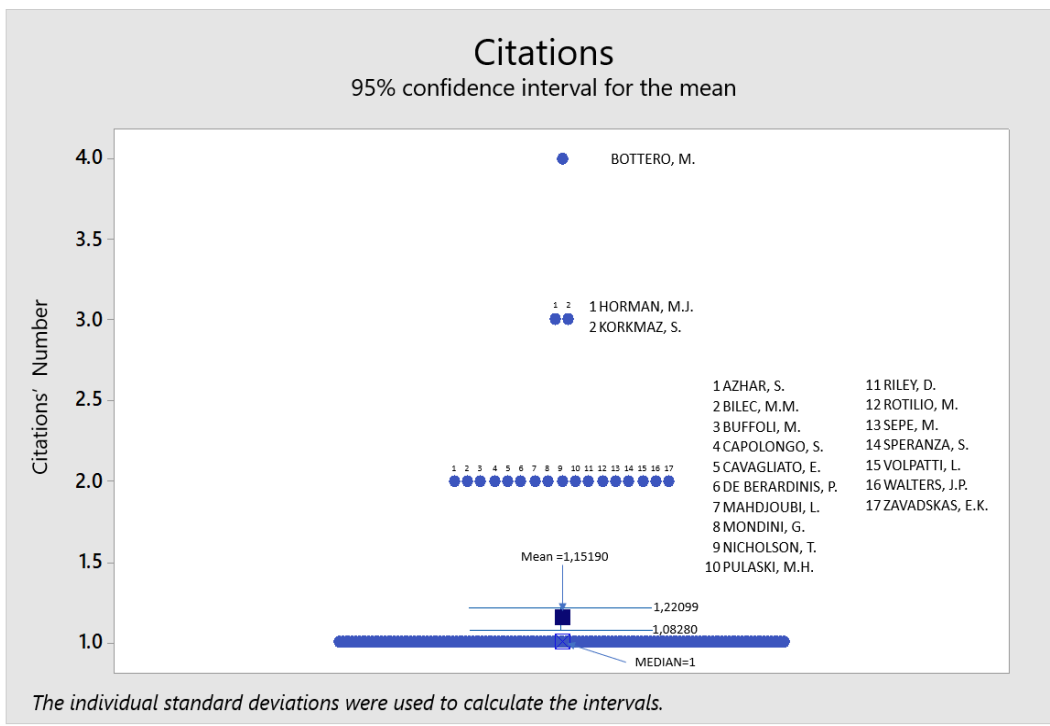

Figure 6. Chart of outliers. Source: Authors. 
Only 3 authors have more than two publications on the sample basis, as shown in Table 3.

Table 3. Authors with more than two citations.

\begin{tabular}{cclc}
\hline Authorship & Number of Publications & \multicolumn{1}{c}{ Affiliation } & Countries \\
\hline Bottero, M. & 4 & Polytechnic di Torino & Italy \\
\hline Horman, MJ & 3 & Pennsylvania State Univ. & U.S \\
\hline Korkmaz, S. & 3 & $\begin{array}{l}\text { School of Planning, } \\
\text { Design, and Construction }\end{array}$ & U.S \\
\hline
\end{tabular}

Source: Authors.

Although, the results of Table 3 appear to confirm the assumptions of Lotka's law, since only a small number of authors have had more than 2 publications. In all, sampling provided 157 authors, with only $2 \%$ having more than two publications, $10 \%$ having 2 publications and $88 \%$ only 1 publication.

The most cited article by Marta Carla Bottero is titled: "Decision making and cultural heritage: An application of the Multi-Attribute Value Theory for the reuse of historical buildings" published in the Journal of Cultural Heritage in the year 2013, in which she is co-author with Giulio Mondini, with Valentina Ferretti as the lead author. This work has \#36 and analyzes the problem of sustainability assessment in cultural heritage projects, using the MAVT (Multi-Attribute Value Theory). It carries out a case study on the reuse of historical buildings in the metropolitan area of Turin (Italy), exploring the MAVT contribution to decision problems in the field of cultural heritage.

In turn, the most cited article by Michael J. Horman was published in 2005, titled: "Continuous value enhancement process" published in the Journal of Construction Engineering and Management in which he is co-author, with Michael $\mathrm{H}$. Pulaski as lead author. The work aims to integrate sustainable demands into project management practices by developing a process-based model for detailing sustainability-related project decisions in high-performance civil construction. The methodology used was two case studies to determine if the Continuous tool Value Enhancement Process (CVEP) was able to systematically identify design solutions that improve project performance and increase sustainability levels and has 24 Scopus citations.

The author Sinem Korkmaz holds the highest citation in the article: "Project delivery metrics for sustainable, high-performance buildings" published in the Journal of Construction Engineering and Management in 2011, in which he is co-author with David R. Riley and Lipika Swarup lead author. The study adopts defined evaluation metrics to show descriptively the extent to which relationships and the influence of project delivery attributes, such as owner commitment, team integration, and contractual relationships, affect the project's sustainability goals. Its methodology is the case study and qualitative methods of analysis to evaluate and verify the metrics of project delivery at the desired level of sustainability and projects. This article has 30 citations.

Table 4 presents a summary of works with two or more citations in the database of this research and information as: authors, year of publication, article title, periodical, objective and method. 
Table 4. Summary of most cited papers

\begin{tabular}{|c|c|c|c|c|c|}
\hline Authors/Year & Tittle & Journal & Objective & Methodology & \\
\hline $\begin{array}{l}\text { Ferretti et al. } \\
(2014)\end{array}$ & $\begin{array}{l}\text { Decision making and } \\
\text { cultural heritage: An } \\
\text { application of the } \\
\text { Multi-Attribute Value } \\
\text { Theory for the reuse } \\
\text { of historical buildings }\end{array}$ & $\begin{array}{l}\text { Journal of } \\
\text { Cultural } \\
\text { Heritage }\end{array}$ & $\begin{array}{l}\text { To analyze the } \\
\text { problem of } \\
\text { sustainability } \\
\text { assessment in } \\
\text { cultural heritage } \\
\text { projects. }\end{array}$ & Case study & 4 \\
\hline $\begin{array}{l}\text { Pulaski \& } \\
\text { Horman (2005) }\end{array}$ & $\begin{array}{l}\text { Continuous value } \\
\text { enhancement } \\
\text { process }\end{array}$ & $\begin{array}{l}\text { Journal of } \\
\text { Construction } \\
\text { Engineering } \\
\text { and } \\
\text { Management }\end{array}$ & $\begin{array}{l}\text { Integrate sustainable } \\
\text { demands into project } \\
\text { management } \\
\text { practices through a } \\
\text { process-based model } \\
\text { to detail sustainable } \\
\text { decisions in civil } \\
\text { construction projects. }\end{array}$ & Case study & 3 \\
\hline $\begin{array}{l}\text { Swarup et al. } \\
(2011)\end{array}$ & $\begin{array}{l}\text { Project delivery } \\
\text { metrics for } \\
\text { sustainable, high- } \\
\text { performance } \\
\text { buildings }\end{array}$ & $\begin{array}{l}\text { Journal of } \\
\text { Construction } \\
\text { Engineering } \\
\text { and } \\
\text { Management }\end{array}$ & $\begin{array}{l}\text { Show descriptively } \\
\text { the extent to which } \\
\text { relationships and the } \\
\text { influence of project } \\
\text { delivery attributes. }\end{array}$ & $\begin{array}{l}\text { Case and } \\
\text { qualitative } \\
\text { study }\end{array}$ & 3 \\
\hline $\begin{array}{l}\text { Azhar \& Brown } \\
(2009)\end{array}$ & $\begin{array}{l}\text { Bim for sustainability } \\
\text { analyses }\end{array}$ & $\begin{array}{l}\text { International } \\
\text { Journal of } \\
\text { Construction } \\
\text { Education and } \\
\text { Research }\end{array}$ & $\begin{array}{l}\text { Investigate the } \\
\text { feasibility of } \\
\text { sustainability } \\
\text { analyzes based on } \\
\text { BIM. }\end{array}$ & $\begin{array}{l}\text { Case study } \\
\text { and semi- } \\
\text { structured } \\
\text { interviews }\end{array}$ & 2 \\
\hline $\begin{array}{l}\text { Olinzock et al. } \\
(2015)\end{array}$ & $\begin{array}{l}\text { Life cycle } \\
\text { assessment use in } \\
\text { the North American } \\
\text { building community: } \\
\text { summary of findings } \\
\text { from a } 2011 / 2012 \\
\text { survey }\end{array}$ & $\begin{array}{l}\text { International } \\
\text { Journal of Life } \\
\text { Cycle } \\
\text { Assessment }\end{array}$ & $\begin{array}{l}\text { Clarify the state of the } \\
\text { knowledge of life } \\
\text { cycle assessment in a } \\
\text { population and } \\
\text { understand the } \\
\text { benefits and } \\
\text { perceived barriers to } \\
\text { its application. }\end{array}$ & $\begin{array}{l}\text { Literature } \\
\text { review }\end{array}$ & 2 \\
\hline $\begin{array}{l}\text { Capolongo et al. } \\
(2015)\end{array}$ & $\begin{array}{l}\text { Healthcare } \\
\text { sustainability } \\
\text { challenge }\end{array}$ & $\begin{array}{l}\text { Green Energy } \\
\text { and } \\
\text { Technology }\end{array}$ & $\begin{array}{l}\text { Define solutions and } \\
\text { strategies for } \\
\text { operating hospitals or } \\
\text { sustainable green } \\
\text { projects, in which } \\
\text { sustainability applies } \\
\text { to the main macro } \\
\text { areas. }\end{array}$ & Case study & 2 \\
\hline $\begin{array}{l}\text { Thomas-Alvarez } \\
\text { and Mahdjoubi } \\
(2013)\end{array}$ & $\begin{array}{l}\text { Testing the } \\
\text { effectiveness of a } \\
\text { web-based portal } \\
\text { system for the } \\
\text { building control } \\
\text { sector }\end{array}$ & $\begin{array}{l}\text { Automation in } \\
\text { Construction }\end{array}$ & $\begin{array}{l}\text { Report the content, } \\
\text { design and } \\
\text { functionality of a } \\
\text { portal for the building } \\
\text { control industry. }\end{array}$ & $\begin{array}{l}\text { Comparative } \\
\text { study }\end{array}$ & 2 \\
\hline $\begin{array}{l}\text { Ferretti et al. } \\
(2014)\end{array}$ & $\begin{array}{l}\text { Decision making and } \\
\text { cultural heritage: An } \\
\text { application of the } \\
\text { Multi-Attribute Value } \\
\text { Theory for the reuse } \\
\text { of historical buildings }\end{array}$ & $\begin{array}{l}\text { Journal of } \\
\text { Cultural } \\
\text { Heritage }\end{array}$ & $\begin{array}{l}\text { To analyze the } \\
\text { problem of } \\
\text { sustainability } \\
\text { assessment in } \\
\text { cultural heritage } \\
\text { projects using the } \\
\text { MAVT (Multi-Attribut } \\
\text { Value Theory) } \\
\text { approach. }\end{array}$ & Case study & 2 \\
\hline Sepe (2010) & $\begin{array}{l}\text { Place identity and } \\
\text { placemaker: }\end{array}$ & $\begin{array}{l}\text { Journal of } \\
\text { Urban }\end{array}$ & $\begin{array}{l}\text { It illustrates the } \\
\text { method of site } \\
\text { indicator analysis and }\end{array}$ & $\begin{array}{l}\text { Software } \\
\text { analysis }\end{array}$ & 2 \\
\hline
\end{tabular}


Table 4. Continued...

\begin{tabular}{|c|c|c|c|c|c|}
\hline Authors/Year & Tittle & Journal & Objective & Methodology & \\
\hline & $\begin{array}{l}\text { Planning the urban } \\
\text { sustainability }\end{array}$ & $\begin{array}{l}\text { Planning and } \\
\text { Development }\end{array}$ & $\begin{array}{l}\text { investigates the } \\
\text { construction of } \\
\text { computed indices } \\
\text { from data and } \\
\text { symbols related to the } \\
\text { site identity. }\end{array}$ & & \\
\hline $\begin{array}{l}\text { Gasparro \& } \\
\text { Walters (2017) }\end{array}$ & $\begin{array}{l}\text { Revealing causal } \\
\text { pathways to } \\
\text { sustainable water } \\
\text { service delivery } \\
\text { using FsQCA }\end{array}$ & $\begin{array}{l}\text { Journal of } \\
\text { Water } \\
\text { Sanitation and } \\
\text { Hygiene for } \\
\text { Development }\end{array}$ & $\begin{array}{l}\text { Build the building } \\
\text { regeneration } \\
\text { alternatives available } \\
\text { from the multiple } \\
\text { criteria sustainability } \\
\text { approach. }\end{array}$ & $\begin{array}{l}\text { Qualitative } \\
\text { comparative } \\
\text { analysis }\end{array}$ & 2 \\
\hline $\begin{array}{l}\text { Zavadskas \& } \\
\text { Antucheviciene } \\
(2007)\end{array}$ & $\begin{array}{l}\text { Multiple criteria } \\
\text { evaluation of rural } \\
\text { building's } \\
\text { regeneration } \\
\text { alternatives }\end{array}$ & $\begin{array}{l}\text { Building and } \\
\text { Environment }\end{array}$ & $\begin{array}{l}\text { Classify the building } \\
\text { regeneration } \\
\text { alternatives available } \\
\text { from the multiple } \\
\text { criteria sustainability } \\
\text { approach. }\end{array}$ & Case study & 2 \\
\hline
\end{tabular}

Source: Authors (2019).

Note: \# is the number of citations.

Table 5 presents the periodicals with more than four publications and their respective Impact Factor (IF).

Table 5. Major Journals.

\begin{tabular}{lcc}
\hline \multicolumn{1}{c}{ Journals } & Papers & IF \\
\hline Sustainability Switzerland & 15 & 2.075 \\
\hline WIT Transactions on Ecology and the Environment & 12 & - \\
\hline Journal of Construction Engineering and Management & 7 & 2.201 \\
\hline Architectural Engineering and Design Management & 4 & - \\
\hline Journal of Cleaner Production & 4 & 5,651 \\
\hline Journal of Environmental Management & 4 & 4.005 \\
\hline Journal of Green Building & 4 & - \\
\hline $\begin{array}{l}\text { Proceedings of the Institution of Civil Engineers Engineering } \\
\text { Sustainability }\end{array}$ & 4 & 1,500 \\
\hline
\end{tabular}

Source: Authors. Note: Impact Factor (IF).

It is worth mentioning that Impact Factor (IF) is a global metric used in scientific journals as a way of evaluating them when accounting for citations received. The higher the IF of a journal, the more judicious and rigid will be the evaluation and subsequent publication of a work by the authors. For this reason, the Journal of Cleaner Production has only 4 publications although its IF is 5,651.

The largest concentration of articles by periodicals is in the first third, the known first zone, thus meeting the presuppositions of the law of Bradford. There is also a considerable dispersion of publications in other journals. 
The Sustainability Journal Switzerland aims at promoting advanced studies related to sustainability and sustainable development and is published monthly online by Multidisciplinary Digital Publishing Institute -MDPI. It has been present in the Scopus database since 2009.

The WIT Transactions on Ecology And The Environment covers research on the following subject areas focused on Ecology, Environmental Engineering, Water Resources, Air Pollution, Design and Nature, Sustainable Development, Environmental Health. The periodical participated in the Scopus database from 2006 to 2015, returning in 2017 and continuing until the moment this study was carried out.

The Journal of Construction Engineering And Management publishes research aimed at advancing the science of construction engineering, harmonizing construction practices with theories of design and education, and research in engineering and construction management. Work is directed, but not limited to, the topics of: construction material handling, equipment, production planning, specifications, scheduling, estimating, cost control, quality control, labor productivity, inspection, contract management, management construction, computer applications and environmental concerns. It has been with Scopus since 1982.

Present in the Scopus database since 2005, the journal Architectural Engineering and Design Management addresses specific topics about architecture technology, engineering design, performance and project management, highlighting interfaces between them and bridging the gap between architectural abstraction and engineering practice.

The Journal of Cleaner Production is a transdisciplinary journal focused on the research and practice of Cleaner, Environmental and Sustainable Production. It has been with Scopus since 1993.

The Journal of Environmental Management is geared to unpublished peer-reviewed research for all aspects of management and managing the environment, both natural and artificial. It participated in Scopus in the years 1970, 1973, 1975 and since 1977.

The Journal of Green Building has been with Scopus since 2006 and publishes peer-reviewed articles in the areas of engineering, architecture, construction, construction management, construction science, facility management, landscape architecture, interior design, urban and community planning, and all disciplines related to the built environment.

Proceedings of the Institution of Civil Engineers Engineering Sustainability publishes research on the search and implementation of sustainability principles through engineering planning, design and application. It has been in Scopus since 2004.

Figure 7 shows the co-occurrence network of keywords of the articles in the sample. In it, the size of the nodes indicates the frequency of occurrence and its co-occurrence in the quantity of publications. In addition, the distance from one node to another represents their relationship, for example, the further one node is from the other, the less relationship they will have.

As a limiting criterion, at least 5 occurrences of the keywords were used in the articles in the study database, leading to 90 nodes, organized into 6 different clusters. 


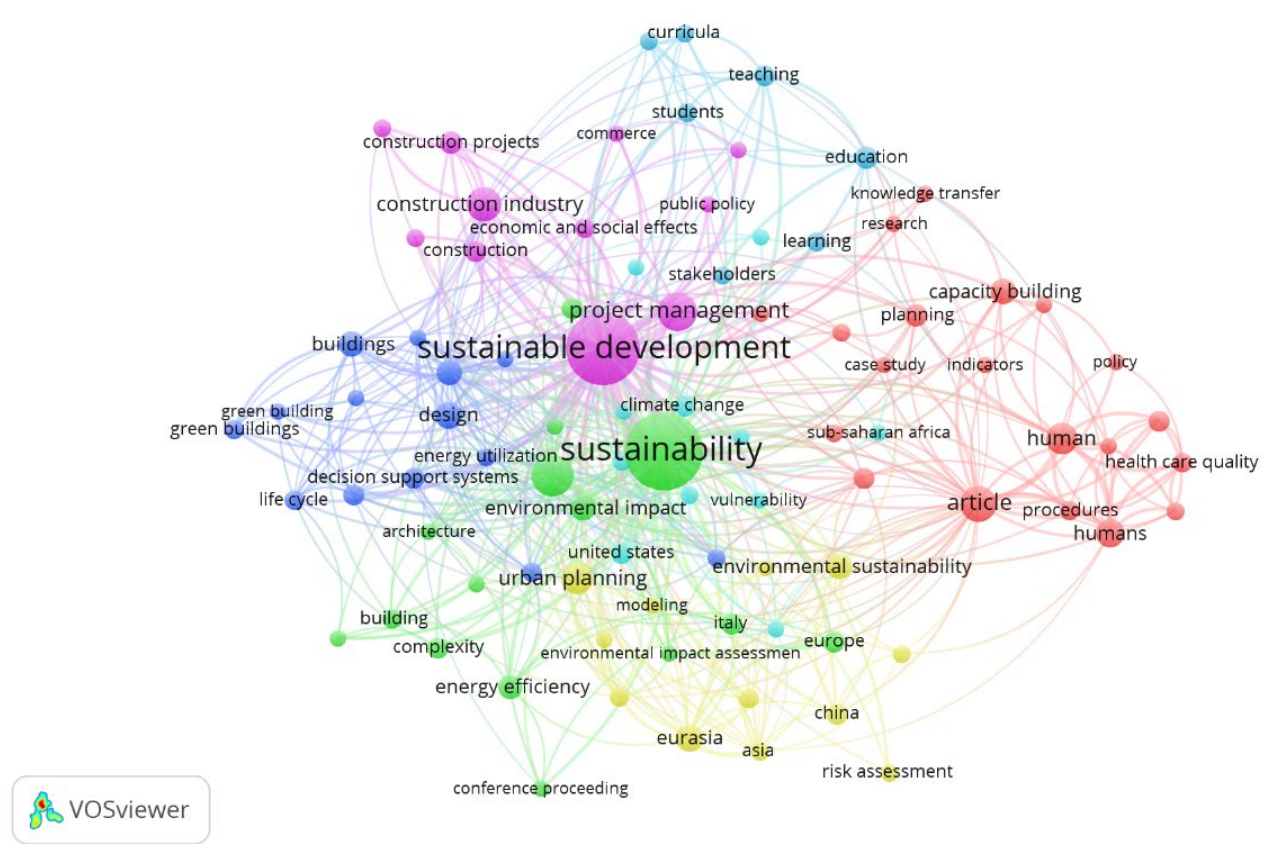

Figure 7. Co-occurrence of keywords. Source: Authors.

Cluster 1 distinguished by the color Lilac has "sustainable development "as the word of greatest frequency, and the other presents denote that the group is directed to researches that analyze the socioeconomic needs of the community through projects of the construction industry. On the other hand, cluster 2 (Green), where sustainability is more prominent, demonstrates that the group is focused on maintaining and balancing the triple bottom line of sustainability by showing words such as: "energy effiency", "environmental impact", "impact assessment", among others. The keywords of cluster 3 (Red) denote research (using as methodology case studies) aimed at health and quality of human life. Cluster 4 (Dark Blue), exposes sustainable building trends, geared towards green project buildings and the application of ecological strategies to construction works. Cluster 5 (Light Blue) is directed to the learning and teaching on issues related to climate issues. Finally, Cluster 6 (Yellow) shows the names of countries, possibly the places where case studies were carried out, and words that denote the need for urban planning.

\subsection{Classification of articles}

The summaries of the 331 articles in the sample of this research were read to evaluate those that relate sustainability to complex construction projects, since, as shown in Figure 5, other areas of knowledge are contained in this sample. After the evaluation by the abstracts, 131 articles were selected and read in full. Of these 131, 94 were the most related to the topic and could be classified (according to Figure 1) in agreement with Akadiri et al. (2012, p .131). Table 6 shows such classification. 
Table 6. Percentages in strategic objectives.

\begin{tabular}{|c|c|c|c|}
\hline \multicolumn{3}{|c|}{ Strategic Objectives of Sustainable Construction } & $\%$ \\
\hline \multirow{4}{*}{ Environmental } & \multirow{4}{*}{ Resource Conservation } & Energy conservation & 18 \\
\hline & & Conservation of Materials & 9 \\
\hline & & Water Conservation & 12 \\
\hline & & Soil Conservation & 7 \\
\hline \multirow{3}{*}{ Economic } & \multirow{3}{*}{ Cost Efficiency } & Initial cost & 18 \\
\hline & & Cost in Use & 11 \\
\hline & & Recovery Cost & 9 \\
\hline \multirow{2}{*}{ Social } & \multirow{2}{*}{$\begin{array}{l}\text { Human Adaptation } \\
\text { Project }\end{array}$} & Protect Health and Comfort & 10 \\
\hline & & Protecting Physical Resources & 7 \\
\hline
\end{tabular}

Source: Authors.

As shown in Table 6, in the environmental category, it was observed that the research mainly addresses issues of increasing scarcity of raw materials, ecosystem impacts caused by the sector, pollution and solid waste generation. Search also means to mitigate the waste of energy in the treatment and improvement of these resources; therefore, it is noteworthy that most of the articles are in the "Resource Conservation" (with the subcategory "Energy Conservation" holding most of articles).

In the economic sphere, priority has been given to the formulation of cost reduction techniques, since with increased competition in the sector observed in the last decade, costs become one of the main market differentials. The authors treated the initial costs as the most important topic, exemplifying us with techniques such as: the rental of machines, outsourcing of services and acquisition of strategic services, which directly affect the reduction of the final costs of the work. It was noted that the use costs feature a rise scenario in the sector mainly due to self-sustainability trend in the works.

In the social field, prevalence was found in addressing issues inherent to the improvement of the local environment, efficient communication, safety and the reduction of discomfort and disturbances. These measures are taken to promote efficient services that can meet the needs of customers seeking building projects. In other engineering projects, researchers address the consequences that large works (such as bridges, highways and dams) can bring communities, whether positive or negative.

The energy conservation subcategory was the most observed (18\%), revealing that the construction of works aimed at the preservation and protection of energy resources are on the rise. Then, water retention (12\%) whose related issues mainly emphasized the coastal regions and maintenance materials (9\%), which showed an improvement in the application of renewable raw materials in the industry. Soil conservation $(7 \%)$ occurred through the implementation of containment works.

Works with lower initial cost corresponded to the greater concern of the sector in relation to cost efficiency (18\%), based on the application of several concepts such as just - in-time and lean construction, jobs that prioritized the reduction. The costs of use are the second most observed subcategory $(11 \%)$, showing a growing concern about 
lower operating costs in the long term. The constructions referring to recovery costs are the last subcategory $(9 \%)$, works with this mainly related to the costs for readaptation of works with high added social value.

The work related to health protection and comfort, correspond to the subcategory most observed in the social aspect $(10 \%)$, with the hospital and social works approach being the most observed, the protection of physical resources $(7 \%)$ mainly addressed issues of social adaptation to better conservation of works.

Of the 34 articles not contained in Table 6, 21\% of these were not found until the time of publication, the $79 \%$ remaining after complete reading research did not meet the requirements.

\section{Conclusions}

The objective of this work was to analyze the publications that correlate complex projects and sustainability, through a bibliometric and systematic literature review and answer the following research question: How is the international scientific production characterized on complex related projects to sustainability?

Despite the growth of environmental movements and UN actions (such as the Stockholm Conference in 1972), the first publication on the subject emerged only in 1987, almost two decades later in relation to the Conference. In addition, only since 2006 we have more than 10 publications per year and a considerable growth in 2012, showing that this theme is emerging.

The United States stands out when it comes to research related to sustainable construction projects. The results of this study showed that the country has the highest number of publications on the subject and the authors who occupy the second and third places in the ranking of most cited authors are also affiliated with American institutions. This may be related to the number of green buildings in the country with Leadership in Energy and Environmental Design certification - LEED, in which the country also leads the world ranking.

LEED has its effective implementation by the year 2000 , which may have directly influenced the research related theme. It was noted that the number of articles published in Scopus from the beginning of the 21st century has continued to grow, with slight variations, and in 2006 the number of publications increased considerably compared to previous years. It should be added that the research areas with more publications identified here are exactly those that the Triple Bottom Line is more present (Social Sciences, Engineering and Environmental Science) and they give subsidies for the criteria for obtaining LEED certification.

In addition, the research methods analyzed are, for the most part, case studies, showing that the studies developed are related to the industry's interest in investing in green technologies. This fact also exposes the influence that project managers have in seeking sustainable solutions, both in the construction itself and in encouraging new research on the subject.

Through the analyzed literature, it was perceived that sustainability must meet the economic, social and environmental criteria and that the maintenance of the balance of these three aspects is loaded with barriers. The difficulties encountered are mainly related to short-term economic issues, such as dynamizing space in ways that favor the quality of life of its occupants, the need for information and the amount of uncertainties. 
In addition, although the case studies presented in Table 4 are directed to the construction of buildings, it is worth remembering that the complexity of projects is present in other types of works, and that for the application of sustainability in their portfolios, managers must take into consideration: the strategic alignment of the organization; integrated management of resources; the scope definitions; the creation of evaluation criteria for performance; and good stakeholder management.

Finally, the results of this research are limited to study the articles present in the selected base, Scopus, not addressing research present in other national databases. For future work, the research could involve other indexing platforms and analysis of scientific papers in other languages.

\section{References}

Akadiri, P. O., Chinyio, E. A., \& Olomolaiye, P. O. (2012). Design of a sustainable building: a conceptual framework for implementing sustainability in the building sector. Buildings, 2(2), 126-152. http://dx.doi.org/10.3390/buildings2020126.

Azhar, S., \& Brown, J. (2009). BIM for sustainability analyses. International Journal of Construction Education and Research, 5(4), 276-292. http://dx.doi.org/10.1080/15578770903355657.

Baccarini, D. (1996). The concept of project complexity: a review. International Journal of Project Management, 14(4), 201-204. http://dx.doi.org/10.1016/0263-7863(95)00093-3.

Barbier, E. B. (1987). The concept of sustainable economic development. Environmental Conservation, 14(2), 101-110. http://dx.doi.org/10.1017/S0376892900011449.

Brent, A., \& Labuschagne, C. (2006). Social indicators for sustainable project and technology life cycle management in the process industry $(13 \mathrm{pp}+4)$. The International Journal of Life Cycle Assessment, 11(1), 3-15. http://dx.doi.org/10.1065/lca2006.01.233.

Brook, J. W., \& Pagnanelli, F. (2014). Integrating sustainability into innovation project portfolio management - A strategic perspective. Journal of Engineering and Technology Management, 34, 46-62. http://dx.doi.org/10.1016/j.jengtecman.2013.11.004.

Brundtland, G. H. (1987). Our common future-Call for action. Environmental Conservation, 14(4), 291-294.

Café, L. M. A., \& Bräscher, M. (2008). Organização da informação e bibliometria. Encontros Bibli: Revista Eletrônica de Biblioteconomia e Ciência da Informação, 13(1), 54-75. https://doi.org/10.5007/1518-2924.2008v13nesp1p54.

Capolongo, S., Bottero, M. C., Lettieri, E., Buffoli, M., Bellagarda, A., Birocchi, M., Cavagliato, E., Dervishaj, A., Noia, M., Gherardi, G., Gola, M., Mantua, F., Miljatovic, S., Nickolova, M., Rostagno, M., Speranza, S., \& Volpatti, L. (2015). Healthcare sustainability challenge. Cham: Springer.

Carter, C. R., \& Rogers, D. S. (2008). A framework of sustainable supply chain management: moving toward new theory. International Journal of Physical Distribution \& Logistics Management, 38(5), 360-387. http://dx.doi.org/10.1108/09600030810882816.

Chueke, G. V., \& Amatucci, M. (2015). O que é bibliometria? Uma introdução ao Fórum. Revista Eletrônica de Negócios Internacionais, 2(10), 1-5.

College of Complex Project Managers, and Defence Materiel Organisation - CCPM. (2008). Competency standard for complex project managers. Commonwealth of Australia: College of Complex Project Managers, and Defence Materiel Organisation.

Csillag, D. (2007). Análise das práticas de sustentabilidade em projetos de construção latino americanos (Dissertação de mestrado). Universidade de São Paulo, São Paulo. http://dx.doi.org/10.11606/D.3.2007.tde-17012008-115248. 
Dyllick, T., \& Hockerts, K. (2002). Beyond the business case for corporate sustainability. Business Strategy and the Environment, 11(2), 130-141. http://dx.doi.org/10.1002/bse.323.

Eid, M. (2009). Sustainable development \& project management: rethinking relationships in the construction industry: integrating sustainable development (SD) into project management (PM) processes. Chisinau: LAP Lambert Academic Pub.

Elkington, J. (1994). Towards the sustainable corporation: win-win-win business strategies for sustainable development. California Management Review, 36(2), 90-100. http://dx.doi.org/10.2307/41165746.

Elsevier. (2018). Scopus content coverage guide. Amsterdam: Elsevier.

Federal Highway Administration - FHWA. (2006). Design-build effectiveness study. Washington: U.S. Department of Transportation.

Ferretti, V., Bottero, M., \& Mondini, G. (2014). Decision making and cultural heritage: an application of the Multi-Attribute Value Theory for the reuse of historical buildings. Journal of Cultural Heritage, 15(6), 644-655. http://dx.doi.org/10.1016/j.culher.2013.12.007.

Gasparro, K. E., \& Walters, J. P. (2017). Revealing causal pathways to sustainable water service delivery using fsQCA. Journal of Water, Sanitation, and Hygiene for Development, 7(4), 546-556. http://dx.doi.org/10.2166/washdev.2017.053.

Gibson, R. B. (2006). Sustainability assessment: basic components of a practical approach. Impact Assessment and Project Appraisal, 24(3), 170-182. http://dx.doi.org/10.3152/147154606781765147.

Gladwin, T. N., Kennelly, J. J., \& Krause, T.-S. (1995). Shifting paradigms for sustainable development: implications for management theory and research. Academy of Management Review, 20(4), 874-907. http://dx.doi.org/10.5465/amr.1995.9512280024.

Glänzel, W. (2003). Bibliometrics as a research field: a course on theory and application of bibliometric indicators. Retrieved in 2019, September 22, from https://www.cin.ufpe.br/ ajhol/futuro/references/01\%23_Bibliometrics_Module_KUL_BIBLI OMETRICS\%20AS\%20A\%20RESEARCH\%20FIELD.pdf

Gorod, A., Hallo, L., \& Nguyen, T. (2018). A systemic approach to complex project management: integration of command-and-control and network governance. Systems Research and Behavioral Science, 35(6), 811-837. http://dx.doi.org/10.1002/sres.2520.

Halliday, S. (2008). Sustainable construction. Londres: Routledge. http://dx.doi.org/10.4324/9780080557168.

Kerzner, B. H. (2012). Recovery project management: techniques and tactics for reversing failing projects understanding troubled projects. New York: International Institute for Learning.

Hu, Y., Chan, A. P. C., Le, Y., \& Jin, R. (2015). From construction megaproject management to complex project management: bibliographic analysis. Journal of Management Engineering, 31(4), 04014052. http://dx.doi.org/10.1061/(ASCE)ME.1943-5479.0000254.

Jiang, J. J., Klein, G., Hwang, H.-G., Huang, J., \& Hung, S.-Y. (2004). An exploration of the relationship between software development process maturity and project performance. Information \& Management, 41(3), 279-288. http://dx.doi.org/10.1016/S03787206(03)00052-1.

Kameiya, M., Romeiro, M., \& Kniess, C. (2016). Boas práticas em gestão de projetos: um estudo na prefeitura de Praia Grande. Revista de Administração da UFSM, 10(5), 870-887. http://dx.doi.org/10.5902/1983465912869.

Kats, G. H. (2003). Green Building Costs and Financial Benefits. Massachusetts Technology Collaborative.

Kerzner, H. R. (2013). Project management: a systems approach to planning, scheduling, and controlling. John Wiley \& Sons. 
Kritskiy, D., Alexander, K., Juliia, P., \& Koba, S. (2018). Modeling the characteristics of complex projects using parallel computing. In Procedings of the 2018 IEEE 13th International Scientific and Technical Conference on Computer Sciences and Information Technologies (CSIT) (pp. 160-163). USA: IEEE. http://dx.doi.org/10.1109/STC-CSIT.2018.8526667.

Maletič, M., Maletič, D., Dahlgaard, J. J., Dahlgaard-Park, S. M., \& Gomišček, B. (2014). Sustainability exploration and sustainability exploitation: from a literature review towards a conceptual framework. Journal of Cleaner Production, 79, 182-194.

http://dx.doi.org/10.1016/j.jclepro.2014.05.045.

Marcelino-Sádaba, S., González-Jaen, L. F., \& Pérez-Ezcurdia, A. (2015). Using project management as a way to sustainability. From a comprehensive review to a framework definition. Journal of Cleaner Production, 99, 1-16. http://dx.doi.org/10.1016/j.jclepro.2015.03.020.

Martens, M. L., \& Carvalho, M. M. (2017). Key factors of sustainability in project management context: a survey exploring the project managers' perspective. International Journal of Project Management, 35(6), 1084-1102. http://dx.doi.org/10.1016/j.jproman.2016.04.004.

Moore, C. B., Payne, G. T., Autry, C. W., \& Griffis, S. E. (2018). Project complexity and bonding social capital in network organizations. Group \& Organization Management, 43(6), 936970. http://dx.doi.org/10.1177/1059601116650556.

Morioka, S. N., \& de Carvalho, M. M. (2016). A systematic literature review towards a conceptual framework for integrating sustainability performance into business. Journal of Cleaner Production, 136, 134-146. http://dx.doi.org/10.1016/j.jclepro.2016.01.104.

Olinzock, M. A., Landis, A. E., Saunders, C. L., Collinge, W. O., Jones, A. K., Schaefer, L. A., \& Bilec, M. M. (2015). Life cycle assessment use in the North American building community: summary of findings from a 2011/2012 survey. The International Journal of Life Cycle Assessment, 20(3), 318-331. http://dx.doi.org/10.1007/s11367-014-0834-y.

Project Management Institute - PMI. (2011). The bottom line of sustainability. Retrieved in 2019, September 22, from https://www.pmi.org/business-solutions/white-papers/bottomline-sustainability.

Project Management Institute - PMI. (2018). Um guia do conhecimento em gerenciamento de projetos. USA: Project Management Institute.

Pulaski, M. H., \& Horman, M. J. (2005). Continuous value enhancement process. Journal of Construction Engineering and Management, 131(12), 1274-1282. http://dx.doi.org/10.1061/(ASCE)0733-9364(2005)131:12(1274).

Romm, J. J., \& Browning, W. D. (1998). Greening the building and the bottom line: increasing productivity through energy-efficient design. Colorado: Rocky Mountain Institute. Retrieved in 2019, September 22, from

https://library.uniteddiversity.coop/Ecological_Building/Greening_the_Building_and_the_Bo ttom_Line.pdf

Sánchez, M. A. (2015). Integrating sustainability issues into project management. Journal of Cleaner Production, 96, 319-330. http://dx.doi.org/10.1016/j.jclepro.2013.12.087.

Sepe, M. (2010). Place identity and PlaceMaker: planning the urban sustainability. Journal of Urban Planning and Development, 136(2), 139-146. http://dx.doi.org/10.1061/(ASCE)07339488(2010)136:2(139).

Silvius, A. J. G., \& Schipper, R. P. J. (2014). Sustainability in project management: a literature review and impact analysis. Social Business, 4(1), 63-96. http://dx.doi.org/10.1362/204440814X13948909253866.

Silvius, A. J. G., Utrecht, S., Schipper, R. P. J., Aetsveld, V., \& Management, C. (2016). Sustainability in project management: a literature review and impact analysis Delivered by Ingenta to: Guest User Delivered by Ingenta to : Guest User. Social Busniess, 4(1), 63-96. http://dx.doi.org/10.1362/204440814X13948909253866. 
Swarup, L., Korkmaz, S., \& Riley, D. (2011). Project delivery metrics for sustainable, highperformance buildings. Journal of Construction Engineering and Management, 137(12), 1043-1051. http://dx.doi.org/10.1061/(ASCE)CO.1943-7862.0000379.

Thomas-Alvarez, N., \& Mahdjoubi, L. (2013). Testing the effectiveness of a web-based portal system for the building control sector. Automation in Construction, 29, 196-204. http://dx.doi.org/10.1016/j.autcon.2012.02.018.

Urbizagastegui, R. (2008). A produtividade dos autores sobre a Lei de Lotka. Ciência da Informação, 37(2), 87-102. http://dx.doi.org/10.1590/S0100-19652008000200007.

van Marrewijk, A., Clegg, S. R., Pitsis, T. S., \& Veenswijk, M. (2008). Managing public-private megaprojects: Paradoxes, complexity, and project design. International Journal of Project Management, 26(6), 591-600. http://dx.doi.org/10.1016/j.jproman.2007.09.007.

Vanti, N. A. P. (2002). Da bibliometria à webometria: uma exploração conceitual dos mecanismos utilizados para medir o registro da informação e a difusão do conhecimento. Ciência da Informação, 31(2), 369-379. http://dx.doi.org/10.1590/S010019652002000200016.

Vargas, R. (2005). Gerenciamento de projetos (6. ed.). São Paulo: Brasport.

Vidal, L., \& Marle, F. (2008). Understanding project complexity: implications on project management. Kybernetes, 37(8), 1094-1110. http://dx.doi.org/10.1108/03684920810884928.

Yildiz, S., Kivrak, S., \& Arslan, G. (2019). Contribution of built environment design elements to the sustainability of urban renewal projects: model Proposal. Journal of Urban Planning and Development, 145(1), 04018045. http://dx.doi.org/10.1061/(ASCE)UP.19435444.0000493.

Zavadskas, E. K., \& Antucheviciene, J. (2007). Multiple criteria evaluation of rural building's regeneration alternatives. Building and Environment, 42(1), 436-451. http://dx.doi.org/10.1016/j.buildenv.2005.08.001.

United Nations. (2017). World population prospects: the 2017 revision. Retrieved in 2019, September 22, from https://www.un.org/development/desa/publications/world-populationprospects-the-2017-revision.html 